\title{
Interactive Multimedia in Teaching Reading
}

\author{
Indah Novita Sari \\ STKIP Muhammadiyah Lumajang \\ (vitacheril@gmail.com)
}

\begin{abstract}
This research is intended to investigate the effectiveness of interactive multimedia for teaching reading in junior high school. Based on my preliminary research, there were many problems in teaching and learning reading for junior high school students. Seeing those problems, the researcher tried to implement the interactive multimedia in teaching reading. Then, the method used in this research is quasi experimental with test as the instrument for collecting the data. The students' score was analyzed using SPSS (independent sample t-test). The result revealed that the statistical value of $t$-test was 4.325 and the degree of freedom of 46 at significant level $5 \%$ was 2.02. It means that the t-value (4.325) is higher than critical value $2.02(4.325>2.02)$. Therefore, the students who were taught using interactive multimedia had better achievement in reading rather than those who were not taught using interactive multimedia.
\end{abstract}

Keywords: interactive teaching, videos, multimedia.

Reading is the process results from a negotiation of meaning between the text and its readers. By reading, students get a lot of information and knowledge from the text. In line with this statement, (Grabe, 2010, p.14) stated that "reading is the process of receiving and interpreting information encoded in language via the medium of print". To get the information, students have to read a book, magazine, newspaper, article in internet, and everything in written language. After reading the book, they can interpret the information and share it to their friends. However, the students found it difficult to read the English text (L2), because they are not accustomed to using English in their daily life and have more exposure in L1(Indonesia) than L2. Therefore, they found it easier to read the Indonesian text (L1) rather than the English text (L2). Whereas, they also need to read the English text because English is the lesson to be learned at school and they cannot graduate from the school when they cannot speak or read English.

Talking about reading, there are some ways to teach and learn about it. Interactive multimedia is one of the was that is effective for teaching and learning reading based on the expert and researchers. (Nisak, 2017, p.32) said that interactive multimedia consists of four sub units, the first is introduction, the second is lesson, the third is exercise, and the last is test. The introduction consists of video and song, it was to brainstorm and activate the students' knowledge about the topic of the day. The lesson consists of the generic structure of narrative text, example of narrative text, vocabulary and text analysis. Exercise and test consist of text with multiple choice questions. It is the complete material to make the students active and interested in learning. She also added that, the interactive multimedia - based supplementary reading material was appropriate for students in the 
eighth grade of junior high school. Besides, (Aloraini, 2012, p.81) mentioned that using multimedia in education is an effective means of reaching a better learning. It means that multimedia was effective and has positive impact on students' academic achievement. Irlidiya et.al (2015) stated that interactive multimedia was effective to improve students' learning outcomes. Students were interested in learning English using interactive multimedia, and their outcomes were also improved

From the aforementioned theories we can infer that interactive multimedia is effective for teaching and learning reading. Therefore, researcher tried to implement the use of interactive multimedia for teaching narrative text in the eighth grade students of SMP Miftahul Huda Sumberbaru, Jember to find out whether the students who were taught using interactive multimedia had better achievement in their reading than the students those who were not.

The problem of this research is "do the students who were though using interactive multimedia have better achievement than the students who were not taught using interactive multimedia. To answer the problem, the researcher did the research in SMP Miftahul Huda Sumberbaru. The researcher used quasi experimental research design, with pre-test and post-test as the instrument. The subjects of this research were VIIIA as control class and VIIIB as experimental class with equivalent ability. Each class consists of twenty four students.

\section{Method}

Quasi experiment with randomized sampling is the design of this research. The objective of the research is to investigate the effectiveness of interactive multimedia in teaching reading for eighth grades students of Junior high school. The researcher conducted the research at SMP Miftahul Huda Sumberbaru, Jember. There were two classes as the object of this research, they were VIIIA and VIIIB. Quasi experimental research was employed, because both classes were having the equal competence. She decided VIIIA as the control group and VIIIB as the experimental group.

Then, the instrument used for collecting the data in this research is test. There were two tests used in it; pre-test and post-test. Both were given to the two classes; control class (class that was not taught using interactive multimedia) and experimental class (class that was taught using interactive multimedia). Pre-test used to find out students' score in reading before the experimental research was conducted. Students in this test were given 70 minutes to do 25 questions of multiple choices. While post-test was used find out the students' reading score after the experimental research was conducted, and in this case students were also given 70 minutes to do the test. The total number of the questions given in the test was similar to the ones in pre-test, but the content was different. Both tests were designed in the form of multiple choices, in which both consist of some short texts and followed by questions related to those. Each of the questions was provided with four options $\mathrm{A}$, $\mathrm{B}, \mathrm{C}$, or D and the students have to select one of options they considered to be the correct answer. Furthermore, before designing the test, researcher consulted to the teacher, matched it with the syllabus and adapted it from the students' hand books and examination test to get a reliable test.

After the data from pre-test was collected, researcher calculated the mean score to know the diversification of students' reading ability between the two classes. Likewise, after the data from post-test was collected, researcher also did what she has done after collecting data in the pre-test. The last, to know the effectiveness of interactive multimedia in teaching reading, researcher analyzed the experimental and control group score in posttest using independents sample t-test. 
Table 1. Pretest Score

\begin{tabular}{lllll}
\hline $\begin{array}{l}\text { Pretest } \\
\text { score }\end{array}$ & Group & $\mathrm{N}$ & Mean & \multicolumn{2}{c}{$\begin{array}{l}\text { Std. Devia- } \\
\text { tion }\end{array}$} \\
\cline { 2 - 5 } & & & \multicolumn{3}{c}{ Control group } & 24 & 44.00 & 3.502 \\
\cline { 2 - 5 } & $\begin{array}{l}\text { Experimental } \\
\text { group }\end{array}$ & 24 & 45.71 & 4.448 \\
\hline
\end{tabular}

Table 2. Posttest Score

\begin{tabular}{|c|c|c|c|c|}
\hline \multirow[t]{3}{*}{$\begin{array}{l}\text { Posttest } \\
\text { score }\end{array}$} & Group & $\mathrm{N}$ & Mean & $\begin{array}{l}\text { Std. Devia- } \\
\text { tion }\end{array}$ \\
\hline & Control group & 24 & 68.33 & 4.993 \\
\hline & $\begin{array}{l}\text { Experimental } \\
\text { group }\end{array}$ & 24 & 73.75 & 3.566 \\
\hline
\end{tabular}

\section{Results and Discussion}

Before conducting the experimental research, the researcher gave the pretest to the students. It was to know the students' score before she applied interactive multimedia in experimental class. After conducting pre-test in control class and experimental class, she got the students' score, and then she calculated the mean score from both classes. The mean score of both classes are shown in Table 1 .

From the data above, the pretest score of control group was 44.00 , and pretest score of experimental group was 45.71 . It means that both groups were having the same achievement because the difference score of both were only 1.71 .

After giving the post-test to the two classes (control and experimental classes), researcher also calculated the mean score of both classes to know the diversification score of both classes, and the mean scores of both can be found in Table 2 .

From the data shown in Table 2, the mean score of control group was 68.33 while the experimental group was 73.75. In this case, the experimental group got higher score than the control group. It meant that, after researcher implementing the interactive multimedia in the experimental class, the reading score of the students in the control class rose significantly than before the implementation of the media. After calculated the mean score of posttest, researcher analyzed the scores using independent sample t-test to know the effectiveness of interactive multimedia in teaching reading in junior high school. The result of independent sample t-test is presented in Table 3.

From Table 3, we know that the researcher used significance two tailed at 5\% significance value. The critical value of $t$ (twotailed) at 5\% significance level with degree of freedom $(\mathrm{df})=46$ was 2.02 . The $t$ value was compared to the critical value. The result of $\mathrm{t}$ value here was 4.325 higher than critical value2.02 $(4.325>2.02)$. The conclusion was $\mathrm{Ha}$ accepted and $\mathrm{H} 0$ rejected. In other words the students who were taught using interactive multimedia performed better achievement in reading than the students who were not taught using interactive multimedia. It showed that interactive multimedia was effective for teaching reading of eight grade students of junior high school.

Before applying the interactive multimedia in the reading class, the researcher conducted pre-test to experimental and control

Table 3. Independent Sample t-test

\begin{tabular}{lllllll}
\hline & & \multicolumn{3}{l}{$\begin{array}{l}\text { Levene's Test for Equality } \\
\text { of Variances }\end{array}$} & \multicolumn{2}{l}{ t-test for Equality of Means } \\
\cline { 2 - 7 } & & $\mathrm{F}$ & Sig. & $\mathrm{T}$ & $\mathrm{df}$ & Sig.(2-tailed) \\
\hline \multirow{2}{*}{ Students score } & Equal variances assumed & 2.352 & .132 & 4.325 & 46 & .000 \\
\cline { 2 - 7 } & $\begin{array}{l}\text { Equal variances not } \\
\text { assumed }\end{array}$ & & & 4.325 & 41.621 & .000 \\
\hline
\end{tabular}


classes. It was to know the students score and students ability in reading. (Brown, 2004, p.3) stated that "A test in simple terms, is a method of measuring a person's ability, knowledge, or performance in given domain". After conducting pre-test, the researcher analyzed the students score from both group. The mean score of experimental group was 45.71 and control group was 44.00 . It means that both classes were having the same score and ability in reading. Then, after conducting the pretest, she started to teach both classes. In this case, she applied the interactive multimedia to teach experimental class. First, she gave the student video with an interesting audio related to the topic. The purpose of doing it was to brainstorm and activate the students' background knowledge about the topic (Narrative Text). While the students were watching the video, she started to activate their background knowledge by giving some questions about the topic. After that, she explained clearly about narrative text which covered; the characteristic of narrative text, the generic structure of narrative text, tenses used in narrative text, and how to read the text clearly. Before she played the video on narrative text, the she made sure that the students understood about narrative text.

Second, she played the video on narrative text. The video was completed with interesting audio. The students watched the video carefully and followed the narrator to read the text below the picture. Sometimes, the researcher paused the video, and told the students to read the text together. It was repeated for several times. The students looked very happy and interested in reading the text. The researcher also helped the students to translate the difficult word in the text in order the students understood more easily the meaning of text. It made the students interested in the text and tried to read it again and again. Once the students have finished reading the text, the she gave some questions based on the text and discussed together to know the students' comprehension.
The third, she gave them the exercise. She gave them a new video on narrative text. Then the students read the text one by one, here she selected some students to read the text. Next, she told the students to answer the questions on a paper. In short, after the students answer the questions, she and the students discussed and gave score on the students' works. The last, she reviewed the topic of the day.

In the contrary, she taught the control group only using LKS and literary books in the school. First, she explained about narrative text clearly, and gave the students examples of narrative text, explained the generic structure and tenses used in narrative text. She told the students to read the narrative text following her. Then she helped the students to translate the narrative text. After that she chose the students randomly to practice reading the narrative text. In short, she gave the examination to the students. Then, they discussed the narrative text and gave the score to the students. The last, she reviewed the topic of the day.

After teaching both classes, the researcher conducted the pos-test to experimental and control group. Then, she got the students post-test score. The mean of posttest score of control group was 68.33 and mean score of post-test score of experimental group was 73.75. After that, the researcher analyzed the score using SPSS especially independent sample t-test. The result of t-value was 4.325; it was higher than critical value at $5 \%$ critical value with 46 degree of freedom was 2.02. It can be concluded that the interactive multimedia is an effective material in teaching reading in eight grade students of junior high school.

Based on the result, the difference between experimental group and control group was very clear. The students that were though by interactive multimedia had better achievement than the students that were not though by it. In the other words interactive multimedia was a media that made the students interested in learning reading. Interactive multimedia was effective for teaching reading, 
especially to improve the students' interest and students' reading skills. ( Richards and Schmidt, 2002, p. 345) explained multimedia as the use of several different types of media for a single purpose, e.g. as in a video that uses film, audio, sound effects, and graphic images. In this research, researcher used video as the media in teaching reading. Here the students were given the interesting videos with a good picture and text in each picture. The students felt happy and interested in watching the videos and started learning reading. It was also able to improve the students' reading ability.

\section{Conclusion}

The mean score of pre-test in experimental class was 45.71 and the mean score of control group was 44.00. Then, the result of mean score of experimental class was 73.75 and mean of control group was 68.33. After getting the mean score of post-test from control and experimental classes, the researcher compared the score and analyzed it by using SPSS, using independent sample t-test.

The result of the data analysis showed that the t-test was higher than t-table at significant rank $5 \%$ with degree of freedom $46(4.325>2.02)$. It can be concluded that the null hypothesis was rejected and the alternative hypothesis was accepted. In other words the students who are taught by interactive multimedia have better achievement in reading than the students who are not taught by interactive multimedia. It seems that interactive multimedia was effective in teaching reading for eight grade students of junior high school.

The result of the research was expected to be useful for the English teacher as an input to use interactive multimedia in teaching reading. For the future researchers who were interested conducting the same research, researcher suggested to use interactive multimedia in teaching other skill in other grades.

\section{References}

Aloraini, S. (2012). The impact of using multimedia on students'academic achievement in the College of Education at King Saud University. Journal of King Saud University - Languages and Translation, 24 (2), 75-82 https://doi. org/10.1016/j.jksult.2012.05.002

Belzegar, N. et al. (2012). The effect of teaching model based on multimedia and network on the student learning (case study: Guidance schools in Iran). Procedia - Social and Behavioral Sciences, 47, 1263-1267

Grabe, W. (2004). Key Issues in L2 Reading Development. New York: Cambridge University Press.

Grabe, W. (2010). Reading in a Second Language, Moving from Theory to Practice. New York. Cambridge University Press.

Halimah, R. (2015). Developing Interactive Multimedia for Teaching Descriptive Text Reading to Grade VII Students at SMPN 6 Yogyakarta. (Thesis). Yogyakarta: Universitas Negeri Yogyakarta.

Irlidiya, et al. (2015). The development of Interactive Multimedia for First-grade Beginning Readers of Elementary school: An Innovative Learning Approach. Language Teaching and Research. 6(3)

Nisak. K. (2017). Developing Interactive Multimedia-Based Supplementary Materials for Reading Instruction in Junior High School. Language Edu. 6(3).

Richards, J.C., and Schmidt, R. (2002). Longman Dictionary of Language Teaching and Applied Linguistics (3rd Ed). London: Pearson Education Limited.

Sharma. P. (2013). Role of Interactive Multimedia for Enhancing Students' Achievement and Retention. International Women Online Journal of Distance Education, 2(3), 12-22 
Smaldino, S.E. et al. (2007). Instructional Technology and Media for Learning 9th Edition. Mahwah: Pearson Education Inc. 